\title{
OMAHA'S EXPERIENCE WITH THE COMMISSION PLAN
}

\author{
BY VICTOR ROSEWATER
}

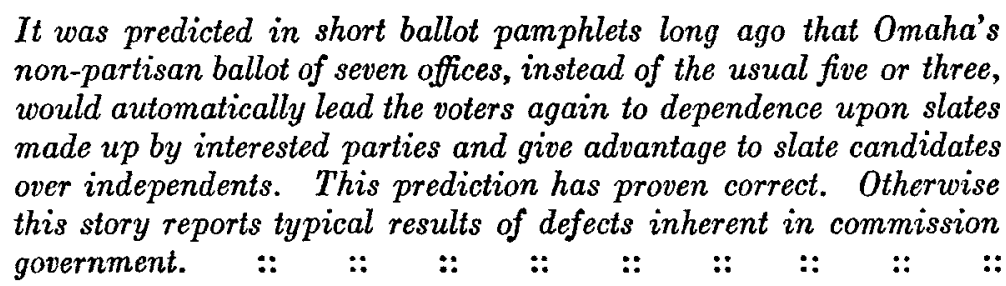

How has commission plan of city government worked in Omaha? Has it met the expectations of its advocates and sponsors? What advantages and what shortcomings has it disclosed in the nine years of its operation? Before answering, the conditions under which the commission plan was originally adopted must be briefly reviewed.

As a consequence of more or less general agitation, the Nebraska legislature of 1911 enacted a commission plan of city government law, to become effective in any city in the state upon ratification at a special election called in response to a petition signed by 25 per cent of the voters. I promptly set in motion the machinery to procure the needful signatures in Omaha, which proved no difficult task, and commission plan government was approved by decisive majority, with no open opposition.

\section{DIVERGENT SOURCES OF SUPPORT}

It may be asked, why was the commission plan so easily "put over?" It was because it received the combined support of usually hostile groups-the dissatisfied, the reformers and the experimentalists, all demanding "a new deal," as well as the then entrenched incumbents who confidently figured that they could hold on readily as city commissioners. The former included the "outs" who wanted to become "ins," the folks with accumulated grievances, the so-called "strict law enforcement" or "Sunday-school" crowd, the idealists and practical reformers who hoped for civic betterment through improved governmental methods. The city hall "machine" embraced the dominant powers backed by the "liberal" element, and the advantage of power and patronage masked behind the leadership of a mayor with admittedly great personal popularity. It was plain that though these forces might join to adopt the commission plan, they were sure after its adoption to clash in a struggle for control. It was plain, too, that the hopes of the different elements were widely divergent and their measuringrods of success or failure by no means identical.

PUBLICITY VALUE OF COMMISSION PLAN

Strange as it may now appear, the mainspring of the commission plan movement in Omaha was a zealous desire to exploit it for advertising purposes. This explains how it came to be fathered by the local Ad Club, which devoted numerous sessions to 
debating the subject and employed and paid an attorney to draft the law. That the advertising possibilities mainly should have attracted such an organization is not at all surprising when we remember that Galveston had, a little while before, reaped a golden harvest of free publicity in newspapers, magazines and public meetings from the transformation of its municipal government following the great tidal wave, and that Des Moines' commission government just at that time was being lauded in print and picture as approaching the municipal millennium. Why should not Omaha do something to draw more serious attention to its push and progress and community achievements than the projection of a "Cowboy Mayor," and what more likely to satisfy this ambition than following in the footsteps of Galveston and Des Moines? Therefore, commission plan made its formal bow under Ad Club auspices. It is entirely safe to assert, however, that the hoped-for harvest of advertising has been dismally disappointing. In the past nine years, Omaha has enjoyed its share of general publicity, good and bad, but little of it is to be credited specially to the adoption of commission plan.

\section{BANISHING PARTISAN POLITICS}

According to prospectus, the commission plan was to divorce the administration of municipal affairs from partisanship, draw into the public service business and professional men hitherto refusing to risk contamination in the cesspool of politics, command by its increased salaries real ability which otherwise could not be induced to leave private employment. The small-bore politicians would, we were assured, see the futility of offering themselves as candidates for commissionerships; the non-partisan ballot would compel people to vote for men rather than for party labels, and enable them to exercise an intelligent choice for only seven instead of $\mathbf{1 7}$ city officers, who, being under no party obligations, would choose subordinates for fitness only, regardless of party service, and keep them alert by permanent tenure and merit promotions.

While the primary ostensibly constitutes a free field for candidates to seek nomination individually and without regard to party affiliations, the competition regularly resolves into a contest between two or three combinations arranged by the candidates themselves or by friends, or clubs, or organizations, promoting their fortunes. And in the make-up of these "slates," the party politics is never overlooked, the design being to frame a ticket enlisting support by reason of the previous party activities of those favored who have been carefully picked with a view to control after election if successful. Such "slates" sometimes carry names for seven places (never fewer than the requisite four to make a majority of the seven), and are generally revised after the primary to replace broken ranks, or to annex outsiders who have demonstrated special strength in the elimination contest, and the lines are thereupon redrawn between two "slates" of seven, those not taken into one being forced by circumstances to put up a combined opposition. Even then the successful "slate" has lost one or more weak members as against the strongest on the other side, the fallen comrades being "taken care of" later with appointive jobs exactly as under the party system. What has really transpired has been a temporary holding in abeyance of party names during the non-partisan election with a campaign waged by two new political parties specially formed for the occasion. 
But election as "non-partisans" has not worked automatically to divest the commissioners of regular party attachments. For example, Omaha's commission plan government was inaugurated by retention of the previously controlling mayor and his associates who had been the beneficiaries of the local Democratic organization, or more correctly speaking, constituted the Democratic "machine." This kept in the city hall the same Democratic contingent, barring a few whom the republican minority succeeded in holding or trading. The "non-partisan" mayor, the very next year, ran for reelection as the Nebraska member of the Democratic national committee; his appointive city clerk was the Democratic county chairman who when rewarded with a federal "plum" passed his political job on to his successor in office; the city hall was the rent-free Democratic headquarters much of the time. When another mayor was installed three years ago he showed himself an equally partisan Democrat only of the other faction; he was forthwith launched by his appointees for the Democratic nomination for governor, but the move was not persisted in and he became executive committeeman of the Democratic state committee; and when the President was prevailed on to appeal to Nebraska voters for a Democrat for United States senator, the letter was addressed to Omaha's Non-Partisan Democratic mayor. After these striking examples no wonder another non-partisan commissioner last year ran and was elected a delegate to the Republican national convention, and afterwards conducted the local campaign as Republican county chairman. When a vacancy occurred owing to the death of one of the commissioners, it was at once agreed to confine consideration of the successor to be named by the Council to applicants of the same political party.

\section{THE QUESTION OF EFFICIENCY}

If increased efficiency of public as of private service means better results for the money, another advantage of commission plan should accrue from more centralized and more responsible organization. The demarcation of the seven departments roughly outlined in the enabling act had to be completed by action of the commissioners.

Administrative functions were distributed among the departments in a manner to reflect the personalities of the commissioners then heading the different departments. The mayor, the repository of all appointing power under the preceding system, retained the larger part of the patronage by expanding the jurisdiction of his department to include positions regarded essential to the "organization." The public library went to the police department, because the police commissioner had once been a member of the library board, and was detached and placed under the street cleaning department when the two superintendents later exchanged places by an enforced transfer. When reassignment of departments was necessitated for a new set of commissioners, a redistribution was effected, taking from the department of public affairs the city clerk, weights and measures, license inspector, market master (added to the department of accounts and finances), custodian of city hall and auditoriums (added to the fire department), and gave it the city chemist. 'The municipal coal yard was allocated to the street cleaning department because it was promoted and established by its superintendent at the time he was in charge of the department of accounts and finances. The council also under- 
took to transfer the asphalt repair plant from the street cleaning to the public improvements department, but reconsidered its decision in order to escape a referendum threatened by the commissioner who objected to being thus deprived of his perquisites.

In Omaha, as elsewhere, and under commission government as previously under its fire and police boards, the police department has been the storm center of controversy and the source of greatest popular dissatisfaction. The commissioner first assigned to that department had to be removed by his colleagues "for the good of the service," and the one who replaced him became so involved that he was the only one refused a renomination when he sought it. Nor has the work of that department run any smoother under his "reform" successor. The practice seems to have been to "unload" the police department with the result of making it an experiment ground for untried police officers constantly changing. At any rate, it has been the department that has drawn the most adverse criticism as compared with the others less in the limelight.

Functioning as members of the city council, the commissioners have worked together with a fair degree of harmony. The inevitable inside combination, however, controls whenever disagreements develop over questions of policy or when the personal prestige of any of the dominant clique must be upheld or defended. This combination is forced at the outset of each administration, when the choice of one of the commissioners for mayor must be made. By these trades desired administrative departments are assured to at least three other commissioners needed to insure a majority. It is exceptional, too, that the same men prove strong as executives and in the council; they may be weak in both capactiies.

\section{THE QUESTION OF ECONOMY}

Economy is but a phase of efficiency and, it goes without saying, is also comparative. The operating expenses of the city have more than doubled during the period and the bonded debt has increased 60 per cent, excluding the issues aggregating $\$ 12$,000,000 for purchase of water and gas plants. Of course, the people have many things to show for the moneyfire department motorized and its strength raised from 208 to 325 men, police force increased from 136 to 263 , parks enlarged, playgrounds added, boulevards laid out, municipal auditorium acquired, municipal coal yard established, street-lighting extended, city hospitals maintained, sewers built, public highways improved by grading, paving and sidewalks.

Special consideration must also be accorded the fact that the area governed has been enlarged by annexation of South Omaha and several suburbs, and that the population served has increased from 125,000 , in the 1910 census to 191,000 in the 1920 census, or by more than 50 per cent, proportionately augmenting the tasks devolving upon the municipal authorities. Incidentally it must be recalled that this period embraced the transition from "wet" to "dry," that it covered all the city's activities in connection with the World War, that it included the readjustments forced by the shortage of labor, change in living costs and sky-rocketing wages and prices, that conditions have been abnormal for commission plan cities as well as for other cities.

\section{RESPONSIVENESS OF COMMISSTON PLAN}

Another advantage claimed for commission government is that it gives an administration more responsive to the 
wishes of the people asserted through initiative, referendum and recall. In these nine years no action has been forced upon the council by initiative proceedings, but the referendum has been twice invoked, once in 1916 upon a street-lighting contract and again in 1918 , as already mentioned, upon a revised apportionment of department functions. The street-lighting contract precipitated a conflict with the management of the water district which denounced this contract as an effort of the electric lighting company to block the embarkation of the water plant into the manufacture and distribution of electric energy. The appeal to the voters resulted in a decisive endorsement of the agreement entered into by the council with the electric lighting company. The second petition for a referendum was instigated by a member of the council to frustrate an alleged attempt of a combine of his colleagues "to freeze him out" of his proper jurisdiction over the asphalt repair plant; in this case, the councilmen rescinded the objectionable ordinance rather than go before their constituency on it.

While talk of recall has been almost continuous, the recall machinery has been but once set in motion. The petition, which presented the names of four commissioners to be removed and four to be substituted, reflected the resentment of certain labor organizations against "unfair treatment" at the hands of the city administration. Upon verification, the signatures proved inadequate and the demand was not pressed further.

Petitions to reopen and resubmit the adoption of the commission plan have been prepared and circulated at least twice without reaching the stage of actual filing. This demand emanated chiefly from residents of sections of the city deprived of representation by the abolition of the system of electing councilmen from wards.

The infrequent resort to these direct vote controls does not, however, by any fair test measure the force exerted through them. The ever-present possibility of invoking a ballot-box verdict of the court of public opinion renders them potentially operative all the time as a spur upon the commissioners to respond to public demands and as a deterrent from acts calculated to arouse public wrath and resentment. This latent power of the petition back of the commission has been frequently evidenced.

\section{GENERAL RESULTS}

As a city Omaha has made visible progress in all directions since adopting the commission plan of government, but whether it has forged ahead faster or slower primarily for that reason is debatable. In many respects, the results have not come up to the roseate promises of its proponents and the plan itself has shown some inherent defects. The consolidation of municipal activities is incomplete, inciting conflict often where there should be harmonious co-operation. The seven commissionerships are at least two too many, producing arbitrary and illogical divisions of authority, to say nothing of unnecessary expense. The consensus of intelligent opinion is that five commissioners would do the administrative work more efficiently and discharge the council duties just as well if not better. The designation of the mayor by the commissioners after the election rather than by the voters in the election has also proved a questionable experiment. The non-partisan ballot does not guarantee invariable choice of the most experienced and dependable candidates for commissioners, and the personal equation and 
individual ability of the officer invested with power and responsibility is still, under this plan as before, the determining factor in the government. The very fact that a demand for return to the mayor and council plan is occasionally heard, and that open agitation for a trial of city manager government is right now going on with apparently increasing favor, indicates that the commission plan, although a change is scarcely imminent, is not sufficiently entrenched in Omaha to discourage advocates of other systems.

\title{
CIVIL SERVICE AND THE POLICE
}

\author{
BY H. W. MARSH \\ Secretary, National Civil Service Reform League
}

The secretary of the Civil Service Reform League takes issue with Mr. Fosdick, author of American Police Systems, regarding the place of civil service examinations in police administration. : ::

Mr. Raymond B. Fosdick, in his book on American police systems, published for the Bureau of Social Hygiene, has paid tribute to the civil service reform movement, but at the same time has made one or two statements which, if true, reflect seriously on the civil service systems as they exist in America to-day. He says, with respect to the application of civil service examinations for the selection of chief of police, that "civil service has too often proved a bulwark for incompetence and neglect to justify oversanguine hope in its extension to this new administrative field." However, in the next chapter he stated that "it is no exaggeration to say that civil service stands between the police and utter demoralization in the cities of the United States."

Mr. Fosdick admits again and again that the difficulty of providing a competent police force in our cities is traceable to local polities. Political influence, he says, is responsible for the constant alteration in our police machinery. Obstacles in the way of complete dominance by party machines have been overcome by the easy processes of law, and police departments have been revamped and reshaped, not in the interests of public service, but to facilitate the operation of the spoils system or strengthen the grip of some political machine. . . The effect of this treatment on police organizations has been peculiarly disastrous. The department has been stunted and dwarfed, with no opportunity for rational development. It has been shaped as a tool of party success, rather than an instrument of public service. Regarded as the legitimate spoils of victory at the polls, it has been prostituted to base and selfish purposes.

\section{WHAT IS THE MERIT SYSTEM?}

Except for Mr. Fosdick's admission, more or less grudgingly made, to the effect that the civil service of the cities of the United States stands between the police systems and utter demoralization, he gives practically no recognition to the improvement in the administration of police departments generally, with the adoption of civil service regulations. $\mathrm{He}$ calls attention to the European treatment of the police problem, where the head of the police department is selected purely and simply on the basis of merit and fitness, and where the head has an absolutely free hand with all appointments, promotions and removals. As Mr. Fosdick says, the problem of the civil 